Article

\title{
Self-assembled three-dimensional carbon networks with accessorial Lewis base sites and variational electron characteristics as efficient oxygen reduction reaction catalysts for alkaline metal-air batteries
}

\author{
Qiyu Wang, Zhian Zhang *, Mengran Wang, Jie Li, Jing Fang, Yanqing Lai \# \\ School of Metallurgy and Environment, Central South University, Changsha 410083, Hunan, China
}

\section{A R T I C L E I N F O}

Article history:

Received 25 February 2018

Accepted 15 April 2018

Published 5 July 2018

\section{Keywords:}

Carbon networks

$\mathrm{N}, \mathrm{S}$ co-doped

Lewis base sites

Charge and spin densities

Oxygen reduction reaction

Alkaline metal-air batteries

\begin{abstract}
A B S T R A C T
Heteroatom-doped carbon has been demonstrated to be one of the most promising non-noble metal catalysts with high catalytic activity and stability through the modification of the electronic and geometric structures. In this study, we develop a novel solvent method to prepare interconnected $\mathrm{N}$, S co-doped three-dimensional (3D) carbon networks with tunable nanopores derived from an associated complex based on melamine and sodium dodecylbenzene sulfonate (SDBS). After the introduction of silica templates and calcination, the catalyst exhibits 3D networks with interconnected 50 -nm pores and partial graphitization. With the increase of the number of Lewis base sites caused by the $\mathrm{N}$ doping and change of the carbon charge and spin densities caused by the $\mathrm{S}$ doping, the designed N, S co-doped catalyst exhibits a similar electrochemical activity to that of the commercial 20 -wt $\% \mathrm{Pt} / \mathrm{C}$ as an oxygen reduction reaction catalyst. In addition, in an aluminum-air battery, the proposed catalyst even outperforms the commercial 5-wt\% Pt/C catalyst. Both interconnected porous structures and synergistic effects of $\mathrm{N}$ and $\mathrm{S}$ contribute to the superior catalytic performance. This study paves the way for the synthesis of various other $\mathrm{N}$-doped and co-doped carbon materials as efficient catalysts in electrochemical energy applications.
\end{abstract}

(C) 2018, Dalian Institute of Chemical Physics, Chinese Academy of Sciences. Published by Elsevier B.V. All rights reserved.

\section{Introduction}

With the rapid development of electric vehicles, high capacity and quick charging ability are required. Metal-air battery is one of the most promising energy storage devices for practical applications [1,2]. However, the sluggish kinetics of the oxygen reduction reaction (ORR) in the cathode impedes the process of electrochemical energy conversion, leading to a high overpotential. Studies on cathode modification mainly focused on catalysts. Although Pt-based catalysts are the most active catalysts [3], their high price and low abundance hinder practical appli- cations. Therefore, studies on non-noble metal catalysts attract significant attention $[4,5]$.

Carbon-based materials have been revealed as alternative ORR catalysts, which can lower production costs and increase the voltage and energy densities of the metal-air battery $[6,7]$. The ORR occurs in the gas-solid-liquid three-phase interface, which requires a stable skeleton and porous structure. Furthermore, nanocarbon has promising catalytic activity and stability; the catalytic properties could be further enhanced by introducing heteroatoms, including $\mathrm{N}, \mathrm{S}$, and $\mathrm{B}$, through modification of the electronic and geometric structures [8-12]. Both

\footnotetext{
* Corresponding author. E-mail: zhangzhian@csu.edu.cn

\# Corresponding author. E-mail: laiyanqingcsu@163.com

This work was supported by the National Natural Science Foundation of China (51674297), the Natural Science Foundation of Hunan Province (2016JJ2137), and the Fundamental Research Funds for the Central Universities of Central South University (2015cx001).

DOI: 10.1016/S1872-2067(18)63089-X | http://www.sciencedirect.com/science/journal/18722067 | Chin. J. Catal., Vol. 39, No. 7, July 2018
} 
theoretical calculations and experimental results revealed that the excellent catalytic activity of NC materials towards ORR originated from the substitution of $\mathrm{C}$ atoms with $\mathrm{N}$ atoms in the $s p^{2}$ lattice of the carbon matrix, which can undermine the electroneutrality of adjacent $\mathrm{C}$ atoms and create positively charged sites conducive to $\mathrm{O}_{2}$ adsorption or splitting. In contrast to the $\mathrm{N}$ atom's action mode, which changes the $\mathrm{C}$ electronic structure owing to its more-positive electronegativity than that of $\mathrm{C}, \mathrm{S}$ possesses a similar electronegativity to that of $\mathrm{C}\left(\delta_{\mathrm{C}}=2.55, \delta_{\mathrm{N}}=\right.$ 3.04 , and $\delta_{\mathrm{S}}=2.58$ ), which could contribute to the increase of the electron spin and further provide active sites for the catalysis of the oxygen reduction. Synergistic effects of heteroatom co-doping contribute to enhance electrocatalytic performances. Chen et al. [13] fabricated N, S co-doped carbon spheres with thiourea as a doping source, phenolic resin as a basement, and F127 as templates, which exhibited a good catalytic activity. Zhang et al. [14] synthesized $\mathrm{N}$ and S co-doped graphene where the matrix material was graphene sheets and N, S sources were a precursor combined by polydopamine (PDA) film and cysteine. However, the irritant sulfurous gas $\left(\mathrm{H}_{2} \mathrm{~S}\right)$ could be easily produced in the decomposition process of short chain chalcogenides.

Melamine is one of the most common materials used to synthesize $\mathrm{N}$-doped carbon owing to its abundant $\mathrm{N}$ content. A common approach to utilize melamine is through a polymerization reaction. Zhang et al. [15] developed porous $\mathrm{N}, \mathrm{P}$ co-doped graphitic carbon by preparing melamine-phytic-acid supermolecule with melamine and phytic acid gathered in a solution of graphene oxide. Liao et al. [16] produced N-doped graphene with $\alpha$-hydroxy acids as carbon source and melamine as nitrogen source. During the processes, the acids can react with melamine to form organic salts to enhance the connection between the carbon and nitrogen sources. In fact, melamine is a type of cross-linking agent, which could generate melamine cation $\left(\mathrm{MA}^{+}\right)$in the solution, which makes it a potential ingredient for an N-based co-doped material. In a solvent environment, anionic surfactant could also ionize an anion group linking with $\mathrm{MA}^{+}$. Sodium dodecylbenzene sulfonate (SDBS) is widely used as an anionic surfactant; the anion group with sulphur reacting with $\mathrm{MA}^{+}$could realize the $\mathrm{N}, \mathrm{S}$ co-doping.

In this study, we present a unique solvent approach to synthesize N, S co-doped three-dimensional (3D) carbon networks based on melamine as an efficient catalyst for ORR and aqueous metal-air battery. The designed 3D carbon networks maintain the pores of regulable silica templates as well as $\mathrm{N}, \mathrm{S}$ co-doped homogeneous networks with cross-linking agents as precursors. With various superior characteristics in the composition, synergistic $\mathrm{N}$ and S co-doping, and 3D structures, the prepared catalysts reveal an enhanced electroactivity benchmarking with a commercial Pt/C catalyst under the same testing electrolytes. The prepared catalyst has comparable properties with those of the commercial Pt/C catalyst in terms of both electrocatalytic activities including the onset and half-wave potentials and battery performances in terms of discharge voltages and energy densities.

\section{Experimental}

\subsection{Material synthesis}

All of the reagents were of analytical purity and used without further purification. In a typical synthesis, $3 \mathrm{~g}$ melamine was dissolved in a hydrochloric acid solution; $1 \mathrm{~g}$ SDBS was dissolved in $20 \mathrm{~mL}$ of deionized water with an addition of $1 \mathrm{~g}$ nanosilica $(\sim 50 \mathrm{~nm})$ after the complete dissolution of SDBS. The above two solutions were then mixed under continuous stirring for $12 \mathrm{~h}$. The mixture was evaporated at $90^{\circ} \mathrm{C}$ to obtain the white residue. The white products were paved in a ceramic boat and then heated to $800{ }^{\circ} \mathrm{C}$ for $2 \mathrm{~h}$ in a tube furnace with a heating rate of $5{ }^{\circ} \mathrm{C} / \mathrm{min}$ under $\mathrm{Ar}$ atmosphere. The final product was denoted as pH-pNSC. In order to better investigate the reaction process, a contrast sample with melamine dissolved in deionized water without silica was synthesized and denoted as NSC; the remaining steps were the same. In order to better show the tunable nanopores, a contrast sample without silica was synthesized and denoted as pH-NSC; the remaining steps were the same.

\subsection{Characterization of the materials}

A field-emission scanning electron microscopy (FESEM, FEI Quanta-200) and a scanning transmission electron microscopy (STEM, MIRA3 TESCAN) were taken to run morphology tests. $\mathrm{N}_{2}$ adsorption/desorption curve were taken with a Quantachrome instrument (Quabrasorb SI-3MP) at $-196{ }^{\circ} \mathrm{C}$. Expressions for chemical states of the carbon, nitrogen and sulfur in the material were performed by X-ray photoelectron spectroscopy (XPS, ESCA LAB 250Xi).

\subsection{Electrochemical measurements}

Eight milligrams of catalysts were dispersed in a solution of $2 \mathrm{~mL}$ ethanol mixed with $8 \mu \mathrm{L}$ of a 5 -wt $\%$ Nafion solution to obtain the test ink. The ORR activity was evaluated by employing an electrochemical workstation (Solartron 1470E) and rotating disk electrode (RDE) technique on a Pine modulated speed rotator (PINE AFMSRCE 3406). The measurement was performed with a three-electrode system in a $0.1 \mathrm{~mol} / \mathrm{L} \mathrm{KOH}$ aqueous solution saturated with $\mathrm{O}_{2}$ at room temperature. The working electrode was fabricated by dropping $5 \mu \mathrm{L}$ catalyst ink on a freshly polished glassy carbon, while the counter and reference electrodes were platinum and $\mathrm{Ag} / \mathrm{AgCl}$ electrodes, respectively. The ORR activity was detected at a scanning potential range of 0.2 to $-1.0 \mathrm{~V}$ by linear sweep voltammetry (LSV) at a speed of $5 \mathrm{mV} / \mathrm{s}$. The durability of pH-pNSC and $20 \mathrm{wt} \% \mathrm{Pt} / \mathrm{C}$ was tested at $-0.30 \mathrm{~V}$ after $10,000 \mathrm{~s}$ in a $0.1 \mathrm{~mol} / \mathrm{L} \mathrm{KOH} \mathrm{solu-}$ tion $(0.1 \mathrm{~mol} / \mathrm{L})$. Further investigations on an aluminum-air battery were performed by fabricating an air electrode using the prepared catalyst; details of the method are presented in Ref. [17] and Supporting Information S2.

\section{Results and discussion}

The synthetic route for pH-pNSC is shown in Fig. 1. Melamine generates a cation in the solution A (Reaction (1)), and 
<smiles>Nc1nc(N)nc(N)n1</smiles>

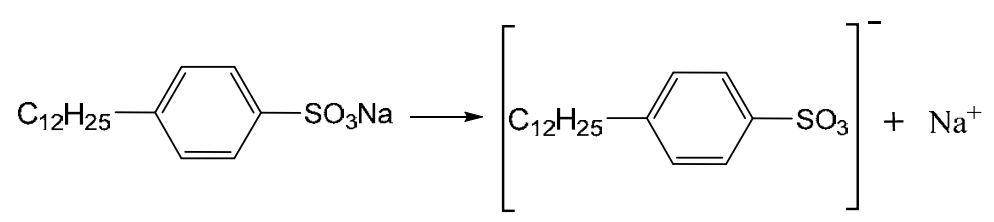

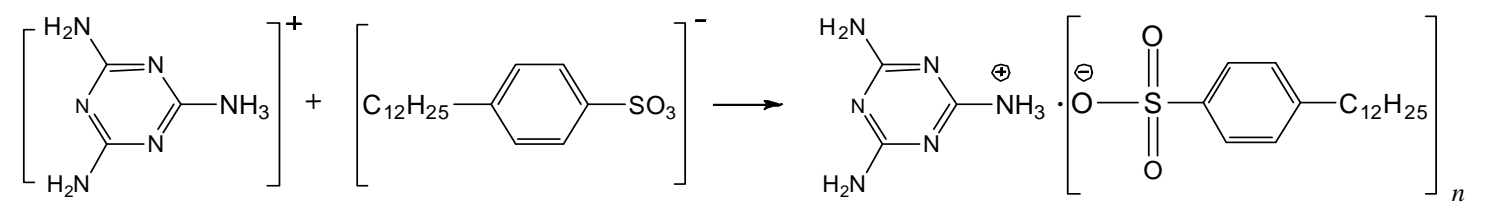
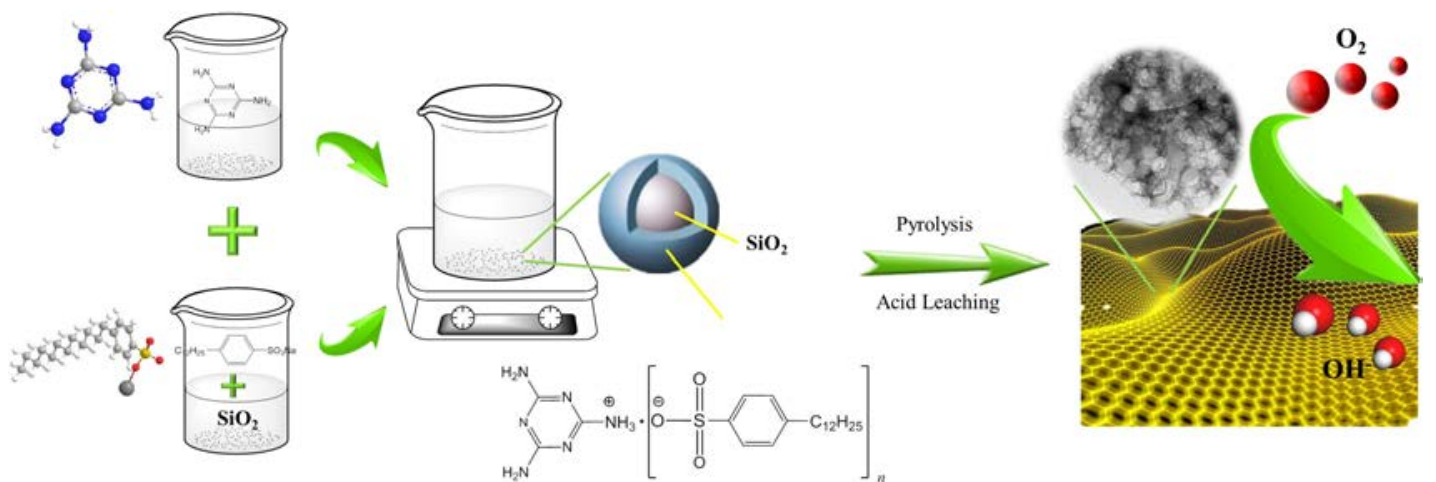

Fig. 1. Schematic illustration of the solvent-melamine-based synthesis of N, S co-doped 3D carbon network catalyst.

SDBS generates an anion in the solution B along with silica nanoparticles (Reaction (2)). When the two solutions are mixed, anion and cation groups combine with an electrostatic attraction as an associated complex. Melamine is a highly symmetric structure, which implies equal chemical activities of all of the three $\mathrm{N}$ atoms in amidogen; therefore, the associated reaction could occur in all three parts. As reported by Wu et al. [18], the surfaces of the added nanoparticles provide a high local concentration of surfactant through electrostatic attraction. Upon the dispersion of the silica nanoparticles in the SDBS solutions, the charged surfaces of the particles may interact with negatively charged anions close to the surfaces of the particles through electrostatic interactions. The associated reaction is induced by aggregation of SDBS and melamine into a bilayer membrane in the acid solution, as described in Fig. S2. Owing to the concentration, vesicles assembled with SDBS and melamine ions were prone to form near the silica and encapsulate simultaneously in the presence of the vesicle-inducing agent [19]. The as-synthesized product MA-(SDBS)n is a suitable precursor to pyrolyze owing to its abundant $\mathrm{N}$ content and chain chalcogenides. Once calcined and acid-leached, the product is as-designed N, S-co-doped carbon with relevant nanopores. In this reaction, melamine- $\mathrm{H}^{+}-\mathrm{SDBS}$ is formed with $\mathrm{NaCl}$ as a byproduct; $\mathrm{NaCl}$ would act on both morphology and carbonization. He et al. [20] demonstrated the $\mathrm{NaCl}$ surface functions as the template to direct the formation of the nanosheet struc- tures in the synthesis. The production of a mass of $\mathrm{NaCl}$ could enable their surfaces to direct the formation of melamine- $\mathrm{H}^{+}$-SDB complex coating, leading to 3D cross-link structures around the silicon templates. On the other hand, $\mathrm{NaCl}$ would melt and flux as a freely moveable liquid above the fusing point form to scour and etch the carbon matrix. The whole carbonization reacts in the colloidal environment [21], dissolving the intermediates of the thermal decomposition of the associated complex to protect skeletons and catalyze the carbonization [22].

The morphologies of the as-obtained carbon NSC, pH-NSC, and $\mathrm{pH}$-pNSC samples are observed using field-emission scanning electron microscopy (FESEM), as shown in Fig. 2(a)-(c). NSC exhibits tight aggregation as the unionized melamine hardly reacts with SDBS. With the pyrolysis of two separated ingredients, the products show unsatisfactory results, different from the expected results. The structures of pH-NSC can be observed in Fig. 2(b) showing conspicuous wrinkled 3D networks. In contrast to NSC, the associating reaction could occur in the acidic solution and the reaction products could generate specialized constructs. Furthermore, Fig. 2(c) presents the final structures of pH-pNSC, where more incompact tissues exist with the help of the silica templates. There are obvious element peaks of $\mathrm{C}, \mathrm{N}, \mathrm{O}$, and $\mathrm{S}$ in the energy-dispersive spectroscopy (EDS) results in Fig. S3. Transmission electron microscopy (TEM) images are shown in Fig. 2(d) and 2(e) to provide fur- 

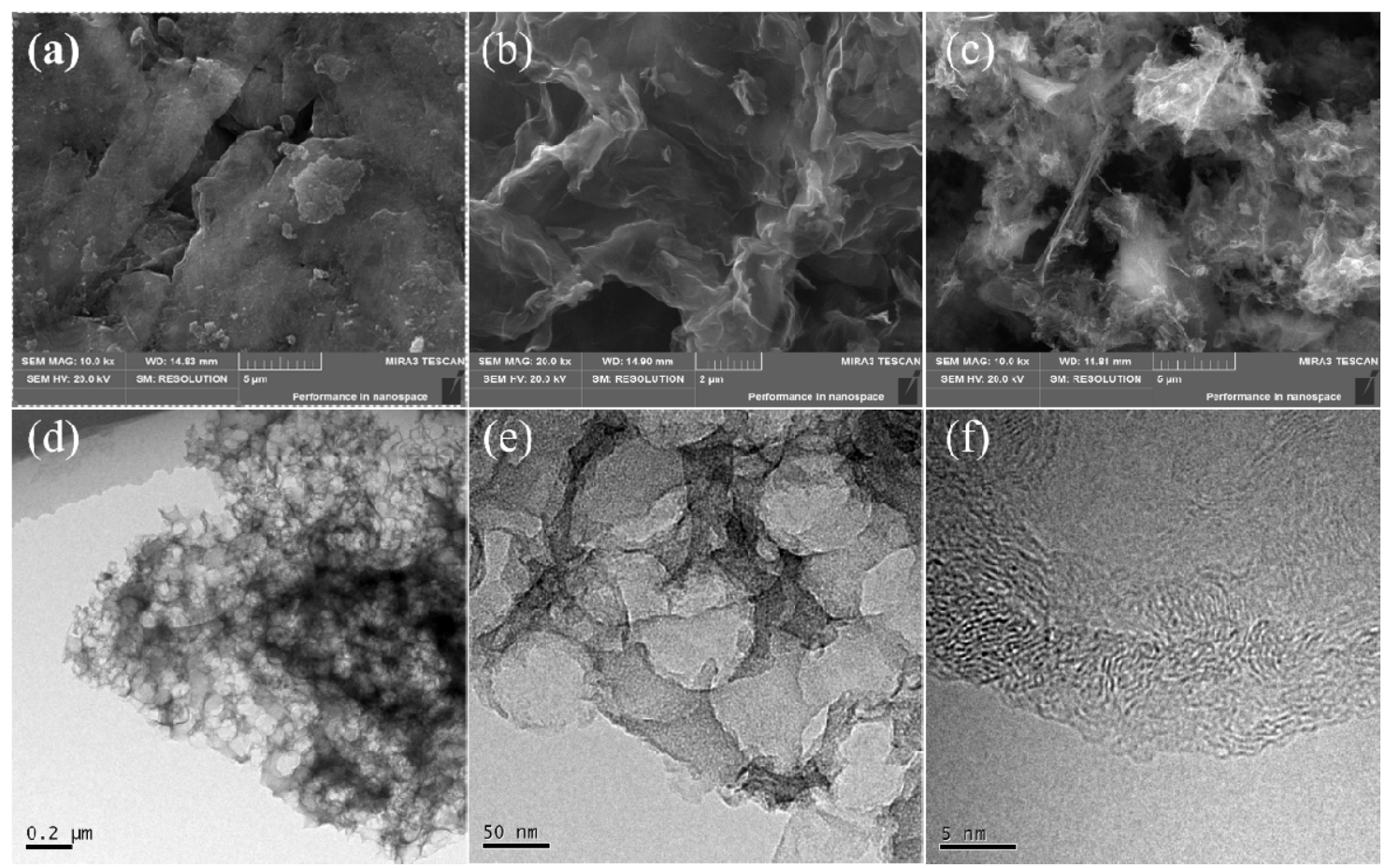

Fig. 2. SEM images of NSC (a), pH-NSC (b), and pH-pNSC (c). TEM (d, e) and HRTEM (f) images of pH-pNSC.

ther details of the internal morphology of the sample. The detailed microstructures in Fig. 2(d) clearly show ample nanopores. The more-specific pore framework in Fig. 2(e) shows that the pore size is $50 \mathrm{~nm}$, which corresponds to the sizes of the templates. The sufficient interconnected porous space inside the material provides a larger number of reaction and adsorption sites to catalyze the oxygen reduction and increase the number of active sites, so that the porous $\mathrm{N}, \mathrm{S}$ co-doped carbon exhibits a higher catalytic activity. As shown in the high-resolution TEM (HRTEM) image in Fig. 2(f), the lattice structures of the edge region show that amorphous carbon appeared with only a partial graphitization [23]. The graphitized parts improve the electroconductivity for a better elec-

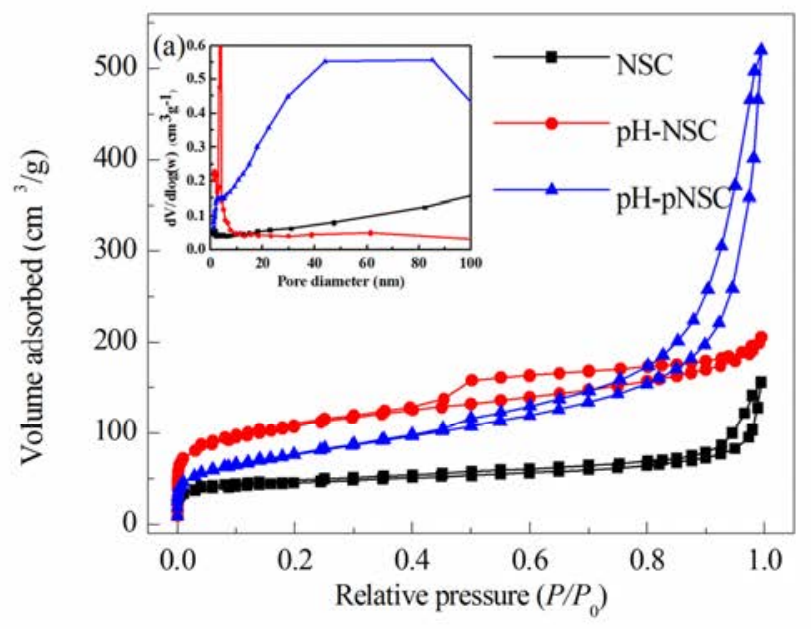

trode performance.

A nitrogen adsorption-desorption test is performed to further investigate the material porosity, as shown in Fig. 3(a). The isotherms for NSC are typical Type I Langmuir isotherms, mostly reversible, corresponding to a micropore structure, while the isotherm for $\mathrm{pH}$-NSC is a typical Type IV isotherm corresponding to a mesoporous structure [24]. The isotherms for pH-pNSC are typical Type II isotherms obtained with a macroporous adsorbent. The steep gas uptake at high relative pressures in pH-pNSC is attributed to the presence of macroporosity. In addition, the Type $\mathrm{H} 3$ adsorption hysteresis of pH-pNSC represents abundant slit-shaped pores and edge structures $[25,26]$. The surface areas could be evaluated by

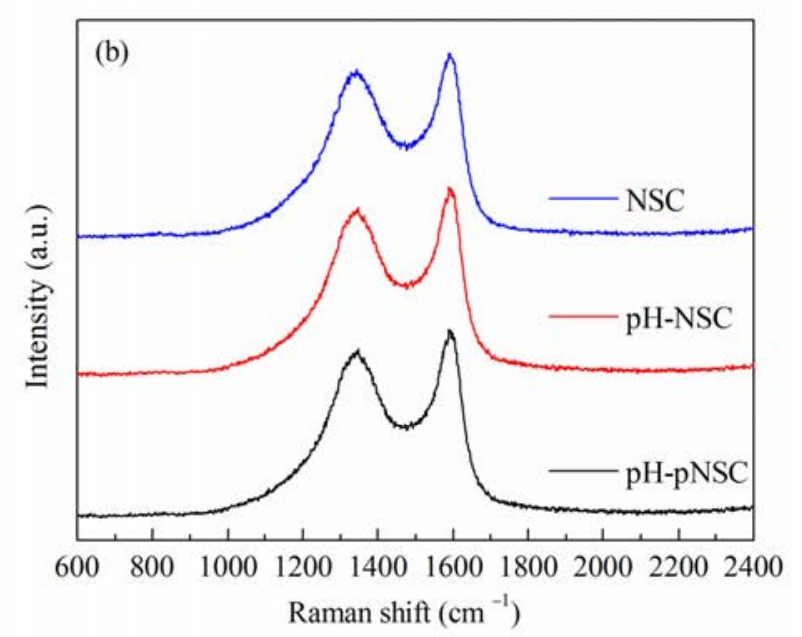

Fig. 3. (a) Nitrogen adsorption-desorption isotherms of NSC, pH-NSC, and pH-pNSC; The inset shows the pore size distributions of NSC, pH-NSC, and pH-pNSC; (b) Raman spectra of NSC, pH-NSC, and pH-pNSC. 
fitting Brunauere-Emmette-Teller (BET) equations; the estimated surface areas are $164.7,274.9$, and $385.1 \mathrm{~m}^{2} / \mathrm{g}$ for the NSC, pH-NSC, and pH-pNSC samples, respectively. The increase of the surface area is attributed to the higher extent of reaction and richer pores. The pore distribution results are shown in the inset of Fig. 3(a). There is only a small peak in the range of 1-2 $\mathrm{nm}$ for NSC. The micropores in NSC are accumulation gaps owing to its tight aggregation shown in the SEM image for the unreacted raw material. A sharp peak appears at $4 \mathrm{~nm}$ in the pore distribution curve of pH-NSC; in addition, a small peak appears at 3-4 nm in pH-pNSC. A more significant peak of pH-pNSC sites is observed at $50 \mathrm{~nm}$, which matches the templates' size. The results show that $\mathrm{pH}-\mathrm{pNSC}$ inherits the porous structures of $\mathrm{pH}-\mathrm{NSC}$, and retains the pores produced by the silica templates. The porous structures improve the adsorption property of the sample to further enhance the catalytic activity.

Raman spectra of the three samples shown in Fig. 3(b) reveal the different graphitic nature of the carbon lattice. The two peaks at 1,350 and $1,590 \mathrm{~cm}^{-1}$ represent the $\mathrm{D}$ and $\mathrm{G}$ peaks of the graphitic carbon, respectively. The ratio of $I_{\mathrm{D}} / I_{\mathrm{G}}$ is widely used to evaluate the disorder in carbon-based materials with a Raman analysis. Based on calculations using the Raman spec- tra, the $I_{\mathrm{D}} / I_{\mathrm{G}}$ ratios are $0.902,0.930$, and 0.930 for the NSC, pH-NSC, and pH-pNSC samples, respectively. The samples with melamine dissolved in an acid solution exhibit similar $I_{D} / I_{G}$ ratios, higher than that for the sample without the acid, which implies that more defects caused by the disordered $s p^{3}$ carbon exist in the carbon lattice [27]. These defects can effectively catalyze the reduction of oxygen as active sites and improve the catalytic performance of the material.

An X-ray photoelectron spectroscopy (XPS) analysis is performed to investigate the surface chemical composition and binding states of pH-pNSC, as shown in Fig. 4. The survey scan spectrum of pH-pNSC shows characteristic spectra of $2 p, \mathrm{~S} 2 s$, $\mathrm{C} 1 s, \mathrm{~N} 1 s$, and $01 s$, confirming that nitrogen and sulfur have been successfully co-doped into the sample. The calculation results show the following contents of the elements: C: $88.13 \%$, N: 7.28\%, S: $1.01 \%$, and 0: 3.58\%. Details of the doped elements of the $\mathrm{N}, \mathrm{S}$ bonding structures in the carbon lattice are revealed by high-resolution XPS, as shown in Fig. 4(b) and 4(c). The fitting results of N $1 s$ XPS spectra in Fig. 4(b) show four types of $\mathrm{N}$ formed in the material: pyridinic- $\mathrm{N}(398.2 \pm 0.2 \mathrm{eV})$, pyrrolic-N (399.6 eV), graphitic- $\mathrm{N}(401.1 \pm 0.2 \mathrm{eV})$, and oxidic- $\mathrm{N}$ structures $[28,29]$. As shown in Fig. 4(c), the S $2 p$ XPS spectra
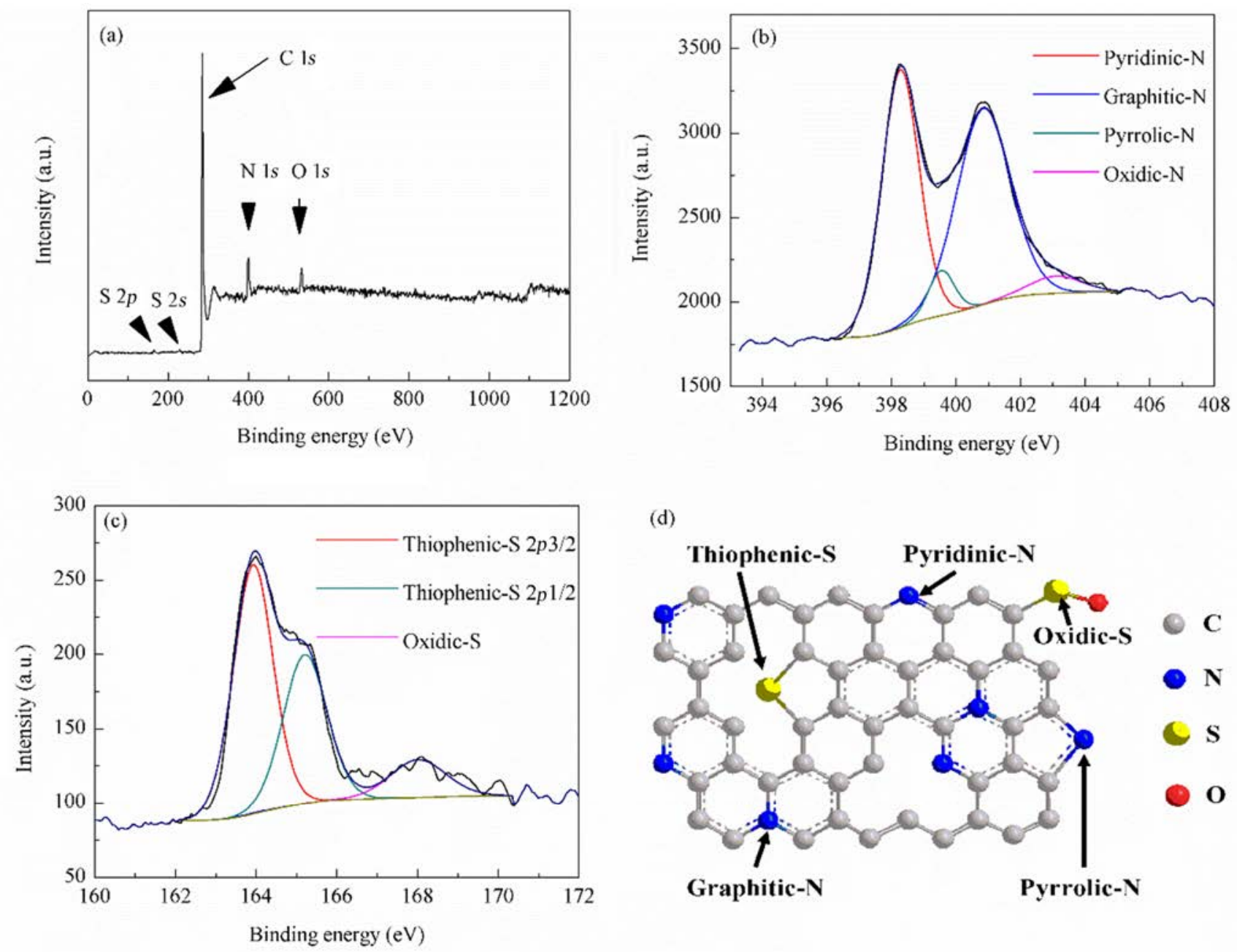

(d)

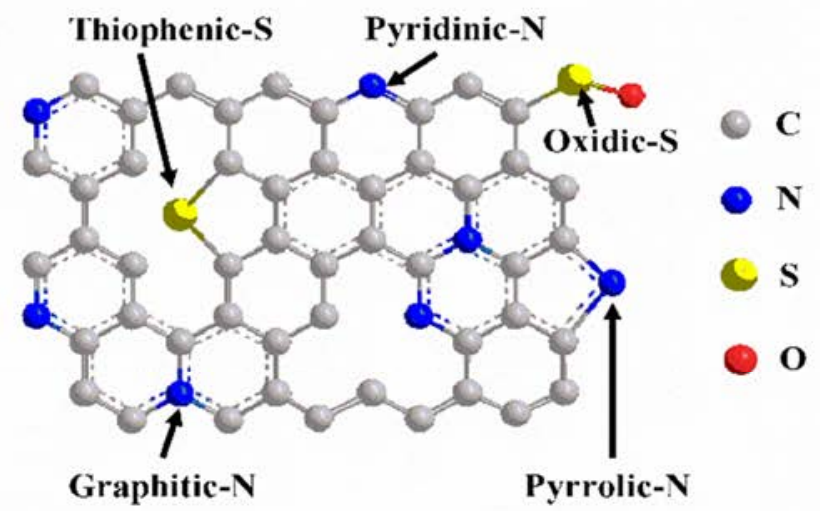

Fig. 4. (a) XPS survey spectra of pH-pNSC; (b) High-resolution N $1 s$ results; (c) High-resolution S $2 p$ results. (d) Schematic of heterocyclic N and S structures in the carbon lattice. 
demonstrates that $\mathrm{S}$ is in forms of thiophenic-S $2 p_{1 / 2}(165.2 \mathrm{eV})$, thiophenic-S $2 p_{3 / 2}(163.9 \mathrm{eV})$, and oxidic-S $\left(-\mathrm{C}-\mathrm{SO}_{x}-\mathrm{C}-(168.1\right.$ $\mathrm{eV})$ ) $[30,31]$. A schematic diagram of these doping elements' structures is shown in Fig. 4(d). Pyridinic- $\mathrm{N}$ at the edges of graphite bonds to two carbon atoms, graphitic- $\mathrm{N}$ inside the graphite lattice bonds to three carbon atoms, while pyrrolic- $\mathrm{N}$ forms a five-membered ring. Thiophenic-S bonds in -C-S- and $-\mathrm{C}=\mathrm{S}-$ corresponding to thiophenic-S $2 p_{3 / 2}$ and thiophenic-S $2 p_{1 / 2}$, respectively.

The electrocatalytic activity of pH-pNSC is primarily evaluated by LSV in $\mathrm{N}_{2}$ - and $\mathrm{O}_{2}$-saturated $0.1 \mathrm{~mol} / \mathrm{L} \mathrm{KOH}$ solutions to confirm the reactant. As demonstrated in Fig. 5(a), the LSV curve for the $\mathrm{N}_{2}$-saturated electrolyte exhibits a typical pseudocapacitive behavior without any significant response, while an obvious reduction peak appears in the curve of the $\mathrm{O}_{2}$-saturated electrolyte. Disparities between the two curves demonstrate the specific reaction based on $\mathrm{O}_{2}$ rather than $\mathrm{N}_{2}$, which is catalyzed by pH-pNSC. A further assessment is performed to estimate and compare the ORR activities of NSC, pH-NSC, and pH-pNSC in the $\mathrm{O}_{2}$-saturated $0.1 \mathrm{~mol} / \mathrm{L} \mathrm{KOH}$ solution using the RDE at $1600 \mathrm{r} / \mathrm{min}$ with commercial 5-wt $\%$ and
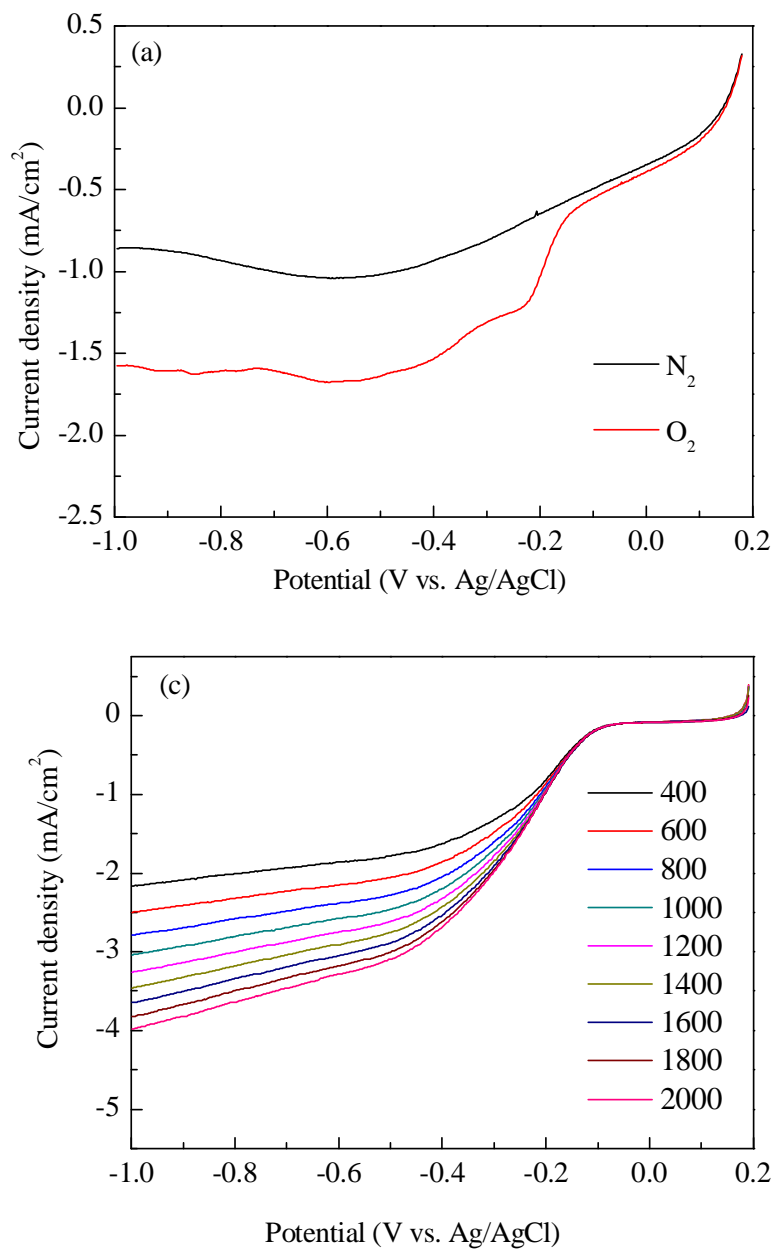

$20-\mathrm{wt} \% \mathrm{Pt} / \mathrm{C}$ as a reference. Among the three NSC samples, as shown in Fig. 5(b), pH-pNSC exhibits the most positive onset potential $E_{0}$ of $-0.08 \mathrm{~V}$, compared with those of NSC $(-0.23 \mathrm{~V})$ and pH-NSC $(-0.11 \mathrm{~V})$. Characterizations of the half-wave potentials $E_{\mathrm{h}}$ are performed, related to the speeds of reaction kinetics, showing that pH-pNSC exhibits a comparable performance with that of pH-NSC $(-0.25 \mathrm{~V})$ and better than that of NSC $(-0.32 \mathrm{~V})$. In contrast, pH-pNSC possesses a similar electrocatalytic performance to that of $20 \mathrm{wt} \% \mathrm{Pt} / \mathrm{C}$ and better than that of $5 \mathrm{wt} \% \mathrm{Pt} / \mathrm{C}$. Considering the $\mathrm{N}, \mathrm{S}$ co-doped synergistic effect and abundant porous structure, pH-pNSC achieves a significantly better catalytic activity than the unreacted NSC and non-porous pH-NSC. In order to study the effect of pH-pNSC in the catalysis of the oxygen reduction, LSV is performed at different rotation speeds with a liner increase between 400 and 2,000 r/min. Electrochemical curves and fitting results are shown in Fig. 5(c) and 5(d). The calculated average electron transfer number for $\mathrm{pH}$-pNSC is 3.41 according to the $\mathrm{K}-\mathrm{L}$ equations [32], as shown in the supporting information, which indicates that the oxygen reduces as: $\mathrm{O}_{2}+\mathrm{H}_{2} \mathrm{O}+4 \mathrm{e}^{-} \rightarrow$ $4 \mathrm{OH}^{-}\left(4 \mathrm{e}^{-}\right) ; \mathrm{O}_{2}+\mathrm{H}_{2} \mathrm{O}+2 \mathrm{e}^{-} \rightarrow \mathrm{HO}_{2}^{-}+\mathrm{OH}^{-}\left(2 \mathrm{e}^{-}\right), \mathrm{HO}_{2}^{-}+\mathrm{H}_{2} \mathrm{O}+2 \mathrm{e}^{-}$
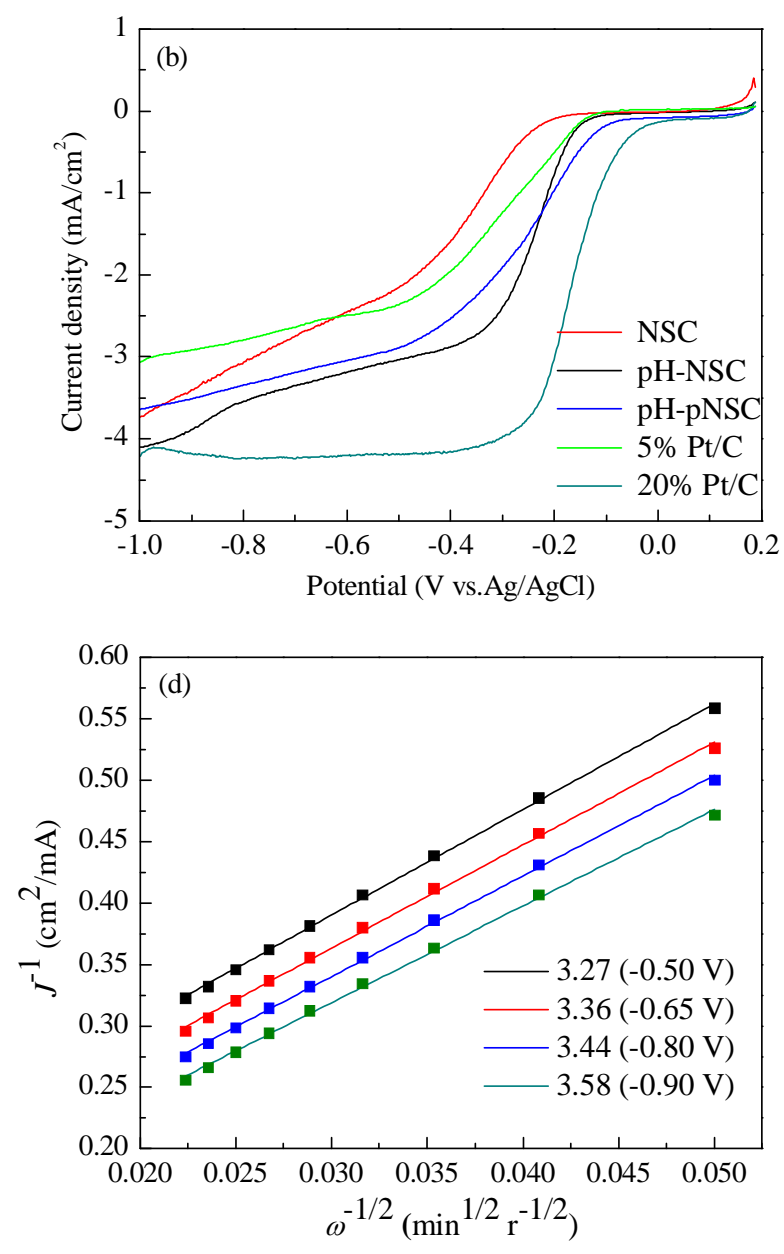

Fig. 5. (a) Cyclic voltammograms of pH-pNSC in $\mathrm{O}_{2}$ - and $\mathrm{N}_{2}$-saturated $\mathrm{KOH}$ solutions (0.1 mol/L); (b) Polarization curves at $1600 \mathrm{r} / \mathrm{min}$ of NSC, pH-NSC, pH-pNSC, 5 wt\% Pt/C, and $20 \mathrm{wt} \% \mathrm{Pt} / \mathrm{C}$; (c) Polarization curves at different rotation speeds for pH-pNSC and (d) corresponding Koutecky-Levich (K-L) plots. 
$\rightarrow 3 \mathrm{OH}^{-}\left(2 \mathrm{e}^{-}\right)$. Therefore, the reaction process is mainly a four-electron-transfer reaction.

For the doped carbon material, the functions of the doping elements should be distinguished by the electronegativities compared with carbon atoms. In an $\mathrm{N}$-doped material, one electron is transferred to the conjugated $\pi$ bond system in pyridinic $\mathrm{N}$ with a long pair of electrons in order to impact the Lewis basicity to carbon. Oxygen molecules can be adsorbed on Lewis base sites; the first step of the oxygen reduction is adsorption on catalysts [33]. In other words, pyridinic $\mathrm{N}$ creates very active sites for the catalysis of the oxygen reduction. For $\mathrm{S}$ doping, in contrast to the effects of $\mathrm{N}, \mathrm{S}$ and $\mathrm{C}$ have similar electronegativities; therefore, the effects of sulfur on changes of the atomic structure of carbon are significantly smaller than those for the nitrogen doping [34]. Therefore, a factor beneficial for the improvement of the ORR catalytic properties could be the altering of the asymmetric electron spin. The covalently bonded sulfur of thiophenic-S and oxidized sulfur at a defected region in a carbon plane including zigzag and armchair sites affect the carbon charge and spin densities. Using density functional theory (DFT) calculations, Zhang et al. [35] reported that electrocatalytic active sites were carbon atoms with the highest spin density, rather than atomic charge density. This implies that the spin density of carbon is crucial for the enhancement of the ORR catalytic activity. Qiao et al. [36] revealed the state of doped $\mathrm{S}$ in a carbon matrix. DFT calculations and natural bond orbital (NBO) analysis indicated that the most significant change in the sulfur's electron distribution was the loss of an electron at the $3 \mathrm{~s}$ orbit owing to its embedment into the carbon framework with $s p^{2}$ hybridization. When the carbon matrix is dual-doped by $\mathrm{S}$ and $\mathrm{N}$, non-paired electrons are subsequently introduced, and the atomic charge/spin density is significantly modified, indicating a higher ORR catalytic performance. With the synergistic effects of $\mathrm{N}$ and $\mathrm{S}$, sufficient active sites are provided for an efficient ORR catalyst. In order to further confirm that the active sites are created by the N, S co-doping, experiments with catalysts with only $\mathrm{N}$ doping or only $\mathrm{S}$ doping are

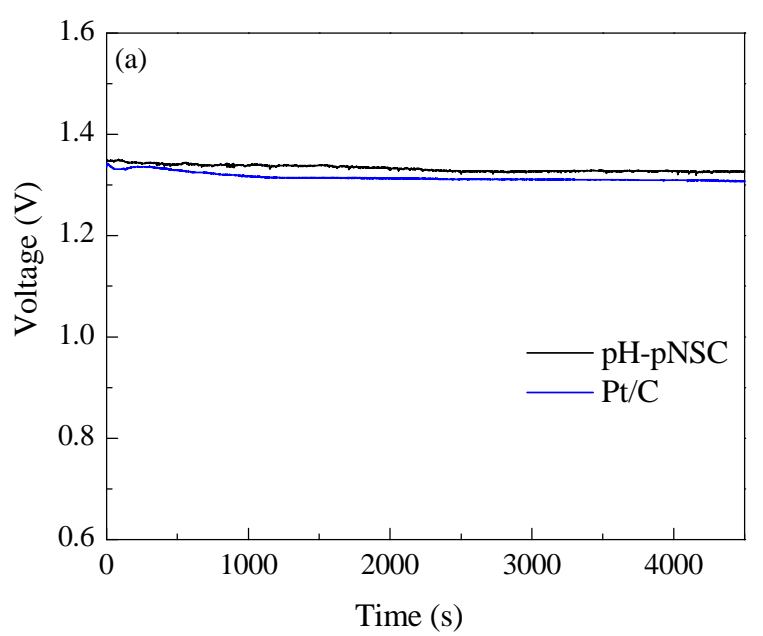

presented in the Supporting Information S4.

The excellent reactant transport provided by the nanopore structures and high electron transfer rates provided by the 3D continuous networks contribute to the highly efficient electrochemical performances of pH-pNSC.

The long-term durability of pH-pNSC was also evaluated, and compared with that of the $20-\mathrm{wt} \% \mathrm{Pt} / \mathrm{C}$ catalyst. As shown in Fig. S7, the pH-pNSC catalyst maintains $81.7 \%$ of the initial ORR current after $10,000 \mathrm{~s}$ of continuous testing, whereas the $\mathrm{Pt} / \mathrm{C}$ catalyst lost $21.4 \%$ of its initial current. These results reveal the superior durability of pH-pNSC with respect to the $\mathrm{Pt} / \mathrm{C}$ catalyst. Moreover, the pH-pNSC catalyst after the 10,000 $\mathrm{s}$ of continuous testing was collected by ultrasound and the change was observed by TEM, as shown in Fig. S8. The original pore structures are destroyed; the red circle outlines the most distinct blurry frameworks. We assume that the loss of the initial current is attributed to the destruction of pore structures. Irregular margins, which replace the regular pores, hinder the adsorption of oxygen and block the active sites of pH-pNSC, thus deteriorate the long-term stability.

As a practical application, the designed catalyst is used to fabricate a primary aluminum-air battery with a pH-pNSC-containing cathode. The air cathode contains a catalyst layer, waterproof air layer made of polytetrafluoroethylene (PTFE), and nickel current-collection layer. As shown by the discharge curves in Fig. 6(a), the cell discharge voltage remains at $1.34 \mathrm{~V}$ for over $4000 \mathrm{~s}$ at a constant current of $50 \mathrm{~mA} / \mathrm{cm}^{2}$, which is $0.02 \mathrm{~V}$ higher than that of the commercial Pt/C catalyst. In order to understand the electrochemical performances of both catalysts upon increases of the current densities, the corresponding voltages and power densities are shown in Fig. 6(b). The voltages of the pH-pNSC- and Pt/C-containing cells decrease with the increase of the current densities; a specific energy density of $123 \mathrm{~mW} / \mathrm{cm}^{2}$ is observed at the peak values of the pH-pNSC sample with current densities of 140 and 150 $\mathrm{mA} / \mathrm{cm}^{2}$. The process of reduction of $\mathrm{O}_{2}$ to $\mathrm{OH}^{-}$is enhanced by the pH-pNSC catalyst, which contributes to the decrease of the

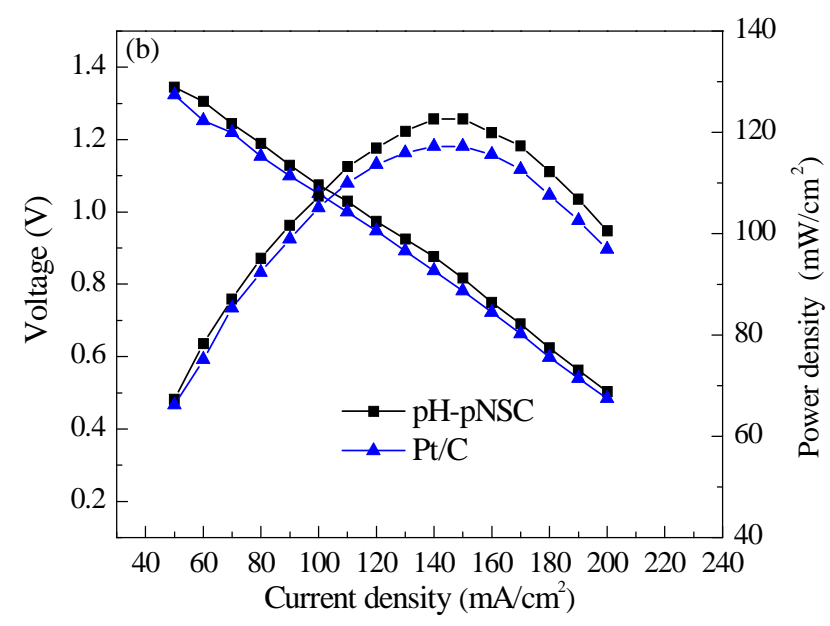

Fig. 6. (a) Discharge curves of pH-pNSC and 5\% Pt/C in an aluminum-air battery. (b) Discharge and power densities of pH-pNSC and 5\% Pt/C at different current densities. 
polarization of the cathode so that the cells exhibit higher discharge voltages and increased power densities.

\section{Conclusions}

Using an associated complex based on melamine as a precursor, a novel solvent method was proposed to synthesize interconnected N, S co-doped 3D carbon networks with tunable nanopores as an efficient electrocatalyst for the catalysis of the oxygen reduction and improvement of the metal-air battery performance. In the solution, melamine generated cations, while SDBS generated anions so that the associated complex was synthesized favorably around fixed-dimension silica templates as the only sources of $\mathrm{C}, \mathrm{N}$, and $\mathrm{S}$. The as-designed pH-pNSC sample exhibited an enhanced electrocatalytic activity, compared with those of the incomplete precursors and non-porous NSC catalysts, which was similar to that of the commercial Pt/C catalyst as an ORR catalyst and outperformed the commercial Pt/C catalysts as cathodes in an aluminum-air battery. Both interconnected porous structures and synergistic effects of $\mathrm{N}$ and $\mathrm{S}$ contributed to the superior catalytic performance. The solvent strategy based on melamine could be employed to synthesize various other N-doped and co-doped carbon materials as highly efficient catalysts in electrochemical energy devices.

\section{References}

[1] B. Y. Xia, Y. Yan, N. Li, H. B. Wu, X. W. Lou, X. Wang, Nat. Energy, 2016, 1, 15006.

[2] H. T. Chung, J. H. Won, P. Zelenay, Nat. Commun., 2013, 4, 1922.

[3] T. Cleve, S. Moniri, G. Belok, K. More, S. Linic, ACS Catal., 2016, 7, $17-24$.

[4] R. Bashyam, P. Zelenay, Nature, 2006, 443, 63-66.

[5] Y. Nie, L. Li, Z. D. Wei, Chem. Soc. Rev., 2015, 44, 2168-2201.

[6] X. J. Liu, S. Z. Zou, S. W. Chen, Nanoscale, 2016, 8, 19249-19255.

[7] L. Y. Zhang, M. R. Wang, Y. Q. Lai, X. Y. Li, J. Mater. Chem. A, 2018, 6, 4988-4996.

[8] J. C. Li, P. X. Hou, S. Y. Zhao, C. Liu, D. M. Tang, M. Cheng, F. Zhang, H. M. Cheng, Energy Environ. Sci., 2016, 9, 3079-3084.
[9] J. F. Kong, W. L. Cheng, Chin. J. Catal., 2017, 38, 951-969.

[10] X. J. Zheng, X. C. Cao, J. Wu, J. H. Tian, C. Jin, R. Z. Yang, Carbon, 2016, 107, 907-916.

[11] Z. Liu, H. G. Nie, Z. Yang, J. Zhang, Z. P. Jin, Y. Q. Lu, Z. B. Xiao, S. M. Huang, Nanoscale, 2013, 5, 3283-3288.

[12] T. F. Hung, S. H. Chen, M. H. Tu, Z. H. Lu, C. K. Chen, R. S. Liu, H. F. Greer, W. Z. Zhou, M. Y. Lo, J. Chin. Chem. Soc., 2014, 61, 93-100.

[13] J. Y. Chen, H. M. Zhang, P. R. Liu, Y. B. Li, G. Y. Li, T. C. An, H. J. Zhao, Carbon, 2015, 92, 339-347.

[14] H. H. Zhang, X. Q. Liu, G. L. He, X. X. Zhang, S. J. Bao, W. H. Hu, J. Power Sources, 2015, 279, 252-258.

[15] J. Zhang, L. Qu, G. Shi, J. Liu, J. Chen, L. Dai, Angew. Chem., 2016, 55, 2230-2234.

[16] Y. L. Liao, Y. Gao, S. M. Zhu, J. S. Zheng, Z. X. Chen, C. Yin, X. H. Lou, D. Zhang, ACS Appl. Mater. Interfaces, 2015, 7, 19619-19625.

[17] Y. Q. Lai, Q. Y. Wang, M. R. Wang, J. Li, J. Fang, Z. Zhang, J. Electroanal. Chem., 2017, 801, 72-76.

[18] X. J. Wu, D. Xu, Adv. Mater., 2010, 22, 1516-1520.

[19] P. Liu, X. Wang, Y. J. Wang, ACS Sus. Chem. Eng., 2014, 2, 1795-1801.

[20] C. N. He, S. Wu, N. Q. Zhao, C. S. Shi, E. Z. Liu, J. J. Li, ACS Nano, 2013, 2, 4459-4469.

[21] W. J. Qian, J. Y. Zhu, Y. Zhang, X. Wu, F. Yan, Small, 2015, 11, 4959-4969.

[22] Y. X. Chen, Z. A. Zhang, Y. Q. Lai, X. D. Shi, J. M. Li, X. B. Chen, K. Zhang, J. Li, J. Power Sources, 2017, 359, 529-538.

[23] W. Ding, L. Li, K. Xiong, Y. Wang, W. Li, Y. Nie, S. G. Chen, X. Q. Qi, Z. D. Wei, J. Am. Chem. Soc., 2015, 137, 5414-5420.

[24] M. Graglia, J. Pampel, T. Hantke, T. Fellinger, D. Esposito, ACS Nano, 2016, 10, 4364-4371.

[25] S. W. Woo, K. Dokko, H. Nakano, K. Kanamura, J. Mater. Chem., 2008, 18, 1674-1680.

[26] K. S. W. Sing, D. H. Everett, R. A. W. Haul, L. Moscou, R. A. Pierotti, J. Rouguerrd, T. Siemiewska, Pure. Appl. Chem., 1985, 57, 603-619.

[27] C. A. Campos-Roldan, G. Ramos-Sanchez, R. Gonzalez-Huerta, J. Vargas Garcia, P. B. Balbuena, N. Alonso-Vante, ACS Appl. Mater. Interfaces, 2016, 8, 23260-23269.

[28] F. B. Su, C. Poh, J. Chen, G. W. Xu, D. Wang, Q. Li, J. Y. Lin, X. W. Lou, Energy Environ. Sci., 2011, 4, 717-724.

[29] T. T. Zhang, C. S. He, L. B. Li ,Y. Q. Lin. Chin. J. Catal., 2016, 37, 1275-1282.

[30] J. Zhang, H. Zhou, X. B. Liu, J. Zhang, T. Peng, J. L. Yang, Y. H. Huang,

\section{Graphical Abstract}

Chin. J. Catal., 2018, 39: 1210-1218 doi: 10.1016/S1872-2067(18)63089-X

\section{Self-assembled three-dimensional carbon networks with accessorial Lewis base sites and variational electron characteristics as efficient oxygen reduction reaction catalysts for alkaline metal-air batteries}

Qiyu Wang, Zhian Zhang *, Mengran Wang, Jie Li, Jing Fang, Yanqing Lai* Central South University

Interconnected $\mathrm{N}$, S co-doped 3D carbon networks with tunable nanopores derived from an associated complex exhibited excellent electrocatalytic and battery performances owing to the increase of the number of Lewis base sites and changes of the carbon charge and spin densities.

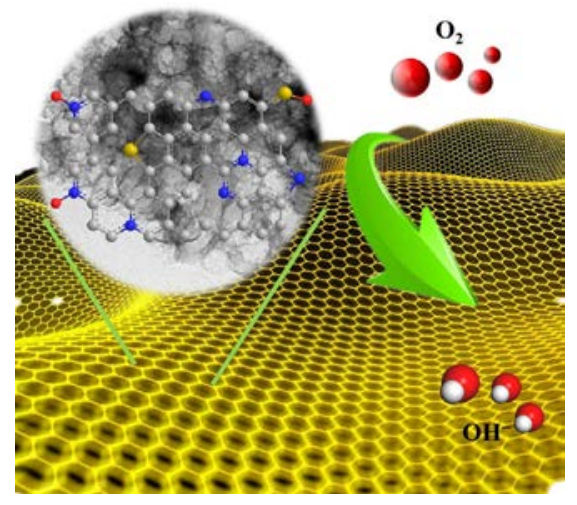


S. C. Mu, J. Mater. Chem. A, 2016, 4, 15870-15879.

[31] Y. Sun, J. Wu, J. H. Tian, C. Jin, R. Z. Yang, Electrochim. Acta, 2015, $178,806-812$.

[32] R. F. Zhou, Y. Zheng, M. Jaroniec, S. Z. Qiao, ACS Catal., 2016, 6, $4720-4728$.

[33] B. S. Shen, H. Wang, L. J. Wu, R. S. Guo, Q. Huang, X. B. Yan, Chin.
Chem. Lett., 2016, 27, 1586-1591.

[34] J. T. Jin, X. C. Qiao, F. L. Cheng, H. B. Fan, L. F. Cui, Carbon, 2017 122, 114-121.

[35] L. P. Zhang, Z. H. Xia, J. Phys. Chem. C, 2011, 115, 11170-11176.

[36] J. Liang, Y. Jiao, M. Jaroniec, S. Z. Qiao, Angew. Chem. Int. Ed., 2012, 51, 11496-11500.

\title{
自组装制备高路易斯碱度和优异电子特性的3D碳网络电催化剂 在碱性金属-空气电池中的应用
}

\author{
王麒羽, 张治安*, 王梦然, 李 劼, 方 静, 赖延清 ${ }^{*}$ \\ 中南大学冶金与环境学院, 湖南长沙410083
}

\begin{abstract}
摘要: 碳材料具有良好的稳定性, 且容易在碳晶格形成缺陷, 具备一定的催化活性, 因此碳材料作为一种可替代贵金属电 催化剂的材料是催化领域的研究热点. 通过杂原子的引进, 可以改变相应碳原子的结构特性, 进而提升其催化活性. 其中 $\mathrm{N}$ 的电负性强于 $\mathrm{C}, \mathrm{N}$ 元素的引入影响 $\mathrm{C}$ 的原子结构使其作为活性位点催化氧气还原. $\mathrm{S}$ 元素与 $\mathrm{C}$ 元素的电负性相近, $\mathrm{S}$ 掺杂的过程中会增大 $\mathrm{C}$ 原子周围的自旋电子密度, 从而增大其对 $\mathrm{O}_{2}$ 的吸附能力, 提高其催化活性. 两种作用方式不同的 掺杂元素之间会形成一种协同效应, 进而提高碳材料的催化活性. 本文采用三聚氧胺的溶剂法制备了三维结构 $\mathrm{N}, \mathrm{S}$ 共掺 杂碳网络. 三聚氧胺和十二烷基苯磺钠在溶液中分布以正、负离子团存在, 以其在二氧化硅模板外形成的缔合物作为前驱 体, 直接制备活性材料. 采用扫描电子显微镜 (SEM), X 射线光电子能谱 (XPS), 拉曼光谱 (Raman) 等手段研究了材料的合 成过程及具有优良催化活性的原因.

SEM, TEM 和 BET 结果表明材料具有良好的孔道结构和较高的比表面积 (385.09 $\left.\mathrm{m}^{2} / \mathrm{g}\right)$. Raman 和 XPS 分析证明了 $\mathrm{N}, \mathrm{S}$ 共掺杂后的材料中碳晶格的缺陷程度明显增大, 而其中存在的吡啶 $\mathrm{N}$ 位于石墨平面的边缘部位, 与两个 C 原子相连, 这种 $\mathrm{N}$ 影响了相连 C 的路易斯碱度, 改善了其吸附氧气能力. 同时, 由 DFT 计算结果可知, 噻吩 S 的存在可以改变相连 C 原子的自旋电子密度, 与掺杂的 $\mathrm{N}$ 原子形成有效的协同作用, 提高其对氧气的催化活性. 相应的电催化性能测试表明, 在 $0.1 \mathrm{~mol} / \mathrm{L} \mathrm{KOH}$ 溶液中, 共掺杂材料的起始电位为 $-0.08 \mathrm{~V}$, 优于其他两种对比材料, 与商用 $\mathrm{Pt} / \mathrm{C}$ 催化剂相近. $\mathrm{N}, \mathrm{S}$ 掺杂显 著提高了碳材料的催化性能, 共掺杂材料表现出了较单一 $\mathrm{N}$ 掺杂更为优异的催化性能. 在铝空气电池放电过程中, 以共掺 杂碳材料制备的空气电极具有优良的放电性能, 在 $50 \mathrm{~mA} / \mathrm{cm}^{2}$ 的电流密度下放电, 电压达到 $1.34 \mathrm{~V}$. 共掺杂材料良好的催 化活性显著减少了空气电极处的极化, 提高了铝空气电池的放电电压. 这种制备方法可为具有此类溶液特性的物质提供 参考, 用以合成相应的掺杂碳材料作为催化剂材料和电极材料.
\end{abstract}

关键词: 碳网络; N, S 共掺杂; 路易斯碱位; 自旋电子密度; 氧还原; 碱性金属-空气电池

收稿日期: 2018-02-25. 接受日期: 2018-04-15. 出版日期: 2018-07-05.

*通讯联系人. 电子信箱: zhangzhian@csu.edu.cn

\#通讯联系人。电子信箱: laiyanqingcsu@163.com

基金来源：国家自然科学基金 (51674297); 湖南省自然科学基金 (2016JJ2137); 中南大学基本科研专项资金 (2015cx001).

本文的电子版全文由Elsevier出版社在ScienceDirect上出版(http://www.sciencedirect.com/science/journal/18722067). 